\title{
The “My Nigga” Haitian
}

\author{
Paul C Mocombe* \\ Department of Sociology \& Philosophy, West Virginia State University, USA
}

*Corresponding author: Paul CMocombe, Department of Sociology \& Philosophy, West Virginia State University, The Mocombeian Foundation Inc, Florida, USA

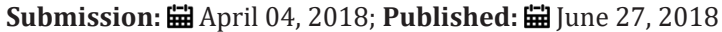

\begin{abstract}
This article puts forth the argument that in the Haitian Diaspora in the United States of America a new Haitian identity has emerged among Haitian youth, which is tied to the black practical consciousness of the black American underclass. The black American in the post industrial

capitalist world-system of America are no longer Africans.Instead, their practical consciousnesses are the product of two structurally differentiated identities, the negro, i.e., black bourgeoisie, or African Americans, on the one hand, under the leadership of educated professionals and preachers; and the "my Nigga," i.e., the black underclass, on the other hand, under the leadership of street and prison personalities, athletes, and entertainers vying for ideological and linguistic domination of black America.

These two social class language games were historically constituted by different ideological apparatuses, the church and education on the one hand and the streets, prisons, and the athletic and entertainment industries on the other, of the global capitalist racial-class structure of inequality under American hegemony, which replaced the African ideological apparatuses of Vodou, peristyles, lakous, and agricultural production as found in Haiti. Among Haitian youth in the US diaspora, post-1986 following the topple of Jean-Claude "baby doc" Duvalier, the latter would come to serve as the bearer of ideological and linguistic domination, forming the "my nigga Haitian" identity.
\end{abstract}

Keywords: African americanization; Racial identity; Religiosity; Black diaspora; Spiritualism

\section{Introduction}

This article puts forth the argument that in the Haitian Diaspora in the United States of America a new Haitian identity has emerged among Haitian youth, which is tied to the black practical consciousness of the black American underclass. The black American in the post industrial capitalist world-system of America are no longer Africans. Instead, their practical consciousnesses are the product of two structurally differentiated identities, the negro, i.e., black bourgeoisie, or African Americans, on the one hand, under the leadership of educated professionals and preachers; and the "my nigga," i.e., the black underclass, on the other hand, under the leadership of street and prison personalities, athletes, and entertainers vying for ideological and linguistic domination of black America. These two social class language games were historically constituted by different ideological apparatuses, the church and education on the one hand and the streets, prisons, and the athletic and entertainment industries on the other, of the global capitalist racial-class structure of inequality under American hegemony, which replaced the African ideological apparatuses of Vodou, peristyles, lakous, and agricultural production as found in Haiti. Among Haitian youth in the US diaspora, post-1986 following the topple of Jean-Claude "baby doc" Duvalier, the latter would come to serve as the bearers of ideo logical and linguistic domination, forming the "my nigga Haitian" identity emerging today.

\section{The Constitution of Haitian Practical Consciousnesses}

If the African and diasporic experience as encapsulated in slavery, colonization, abolitionism, and decolonization dialectically represents the intent of former slaves to be like their masters amidst racism, slavery, colonization, and their structural differentiation, the Africans of Haiti who met at Bois Caïman, August $14^{\text {th }}$, 1791, and other congresses to commence the Haitian Revolution attempted to do the contrary. That is, they, anti-dialectically, rejected not only their slave status, racism, and colonization, but the very practical consciousness of their former slave masters for their own structuring structure or form of system and social integration, i.e., the Vodou Ethic and the spirit of communism social class language game. Their discourse and discursive practices would eventually be supplanted by the practical consciousness or language game of the Affranchis, free (creole) blacks and mulatto, gens de couleur, bourgeoisies, seeking, like their liberal bourgeois black counterparts in America and the diaspora (the black Atlantic), equality of opportunity, distribution, and recognition with their blanc counterparts within the capitalist world-system via the Haitian state and its ideological apparatuses. 
Prior to this usurpation, however, the Vodou and Kreyol ceremony or congress at Bois Caïman under the leadership of Dutty Boukman, Edaïse, Cecile Fatima, the Vodou manbo priestess, is a rejection of both slave status and European civilization, and cannot be, contrary to Susan Buck-Morss's work, Hegel, Haiti, and Universal History, and others, conceptualized within the framework of Hegel's master/slave dialectic, postmodern, post-structural, or postcolonial theories. Whereas, the purposive-rationality of the two bourgeoisies, free landowning blacks and mulatto elites, can be conceptualized within a Hegelian dialectical, postmodern, post-structural, and postcolonial struggle, that of oungan yo, manbo yo, gangan yo, and granmoun yo of Bois Caiman, who would assume the leadership of the masses of the provinces and mountains, cannot. The purposive-rationality of the latter was not a structurally differentiated identity as found amongst the creole blacks and mulatto elites. Oungan yo, manbo yo, gangan yo, and granmoun yo of Bois Caiman offered an alternative structuring structure (form of system and social integration) for organizing the material resource framework and the agential initiatives of social actors, and must not be enframed within the structurally differentiating dialectical, postmodern, post-structural, and postcolonial logic of the West and the Affranchis (today's Haitian mulatto, Arab oligarchy, and petit-bourgeois blacks).

That said, when the Haitian Revolution commences in 1791, there are three distinct groups vying for control of the island, the whites (blancs); free people of color and mulattoes (Affranchis), and the enslaved and escaped (maroon) Africans of the island. The latter, over sixty-seven percent of the population, were not a structurally differentiated other. They had their own practical consciousness, what Paul C. Mocombe calls the "Vodou Ethic and the spirit of communism," by which they went about recursively (re)organizing and reproducing the material resource framework. The former two, free blacks and gens de couleur (Affranchis), were interpellated, embourgeoised, and differentiated by the language, communicative discourse, mode of production, ideology, and ideological apparatuses of the West and shared the same European practical consciousness, the Catholic/Protestant Ethic and the spirit of capitalism social class language game, as the whites. The latter social class language game stood against the Vodou Ethic and the spirit of communism social class language game of the majority of the Africans who were interpellated and ounganified/manboified by the language, communicative discourse, mode of production, ideology, and ideological apparatuses of oungan yo, manbo yo, gangan yo, and granmoun yo [1,2].

The whites, were divided between large plantation owners, grand blanc, and petit-blancs, i.e., managers, slave drivers, artisans, merchants, and teachers. The former, grand blanc, were independent-minded, and like the American colonists wanted political and economic independence from their mother-country, France, where their rights and economic interests were not represented in the National Assembly. The petit-blancs were more racist and feared the alliance between the larger landowners and the Affranchis. The Affranchis were free people of color and mulatto, gens de couleur property and slave owners on the island who shared the religion, culture, language, and ideology of their white counterparts and wanted then Saint-Domingue to remain a French colony.

Although internal antagonism based on race (color) and class existed between the free (creole) blacks and gens de couleur, I group them together under the nomenclature, Affranchis, to highlight the fact that their interpellation and embourgeoisement via the ideological apparatuses of the West rendered their practical consciousnesses identical even though there were racial/color (based on phenotype, not ideology) tensions between them (racial tensions, which still plaques Haiti today). Unlike the majority of white large plantation owners, however, the Affranchis, like Vincent Ogé, André Rigaud, Alexandre Pétion, Pierre Pinchinat, Toussaint Louverture, for examples, did not want independence from France. In the case of the mulattoes, who after independence would come to be referred to as the children of Alexandre Pétion, the first mulatto president of the Haitian Republic, they simply wanted their social, political, and economic rights recognized by France within the colony, not an independent nation-state or the end to slavery.

In regards, to the children of Dessalines/Toussaint, creole slave drivers and free blacks, they sought equality of opportunity, recognition, and distribution vis-à-vis the whites and mulattoes. The enslaved and escaped Africans, metaphorically speaking the children of Sans Souci (the Kongolese general of the Haitian Revolution who was assassinated by the Affranchis Henri Christophe), of the island were divided between field slaves, domestic slaves, and maroons. The domestic slaves, like their African-American counterparts, house slaves, more so identified with their slave masters. However, for the most part, the field slaves and maroons, because of their relative isolation from whites, domestic slaves, gens de couleur, and free blacks, were interpellated and ounganified/man-boified by the modes of production, language, ideology, ideological apparatuses, and communicative discourse of the Vodou Ethic and the spirit of communism, and many sought to reproduce their African ways of life in a national position of their own. In the end, the Revolution would come down to a struggle between the Affranchis and the enslaved and maroon Africans of the island, the latter of whom commenced the Haitian Revolution on August 14th, 1791 at Bois Caiman and other congresses [1-4].

Following the Revolution, between 1804 and 1806, the purposive-rationality of the enslaved and maroon Africans would become a part of the modus operandi of the Haitian nation-state until October 17, 1806 when Jean-Jacques Dessalines was assassinated by Alexandre Pétion and Henri Christophe. At which point, the purposive-rationality of the Affranchis with their emphasis on integration into the global capitalist world-system, capitalist wealth, French culture, religion, and language became dominant at the expense of the African linguistic system, Kreyol; Vodou ideology; its ideological apparatuses; and modes of production, subsistence agriculture, husbandry, and komes, of the African masses on the island who took to the mountains and provinces following the death of Dessalines [2]. 
Contemporarily, the continuous struggle between the mulatto merchant/professional class and the black landowning managerial classes for control of the state and its apparatuses, at the expense of the African masses in the provinces and mountains whose children they arm and use against each other as they migrate to Portau-Prince amidst American neoliberal policies seeking to displace the masses off their land for tourism, agro and textile industries, and athletics (basketball and soccer), continues to be a hindrance for the constitution of a sovereign Haitian nation-state. The former two, interpellated and embourgeoised in Western ideological apparatuses, seek to constitute Haiti, with the aid of whites (France, Canada, and America), as an export-oriented periphery state within the capitalist world-system under American hegemony against the desires of the masses of Africans in the provinces and mountains seeking to maintain their komes, subsistence agriculture, and husbandry, which are deemed informal.

The grandon class, composed of educated professionals, former drug dealers, entertainers, and police officers attack the former Affranchis class, which is now a comprador bourgeoisie (composed of mulattoes, blacks, and Arab merchants) seeking to build, own, and manage hotels and assembly factories producing electronics and clothing for the US market, under the moniker the children of Dessalines against the children of Pétion in the name of the African masses of the island, the majority of whom are peasant farmers interpellated and ounganified by the Vodou Ethic and the spirit of communism. Instead of focusing on vertically integrating the lakou system and infrastructure (artificial lakes, potable water, food security, mache modern market spaces for komes, universities, and state-owned companies for the peasant class to sell, etc.) to augment national agriculture and the productive forces of the latter group, who constitute eighty-five percent of the population, the mulatto elites and petit-bourgeois blacks emphasize job creation through foreign direct investment in tourism, agro and textile industries, privatization of public services, infrastructure for an export-oriented economy similar to the one they had under slavery, and the constitution of a political bourgeoisie in control of the state apparatuses. However, their inabilities given the voting power of the majority-to constitute two dominant rotating political parties to implement the desires of their former colonial slave masters, leaves Haiti in perpetual turmoil. As in slavery, the African masses continue to fight, against their interpellation, embourgeoisement, and differentiation as wage-earners (commodities) in the tourism trade and textile factories of the Catholic/Protestant Ethic and spirit of capitalism of these two power elites seeking to displace them off their lands and into urban centers of Haiti and elsewhere to facilitate capitalist development. This dislocation of the African masses of Haiti to urban centers at home and abroad have led to the emergence of new identities amongst them as they scatter throughout the world in search of better opportunities in the face of neoliberal policies on the island. For example, Haitian immigration to the United States most recently has seen the rise of what is more appropriately labelled the "my nigga" Haitian identity, which is tied to the "my nigga" black American underclass consciousness of the inner-cities.

\section{The Constitution of Black American Practical Consciousness}

Black American social agency was constituted by and within the dialectic of the American Protestant capitalist social structure of racial-class inequality. Unlike the African Haitians, the children of Sans Souci, no African ideological apparatuses were put in place to reorganize and reproduce an African worldview on the American landscape. The African body, which embodied its initial African practical consciousnesses that were reified in Africa, were thrown in, interpellated by, and socialized (embourgeoised) in new "white" capitalist ideological apparatuses that they would subsequently adopt and reproduce, i.e., the black church, nuclear family, etc., in regards to the politics of their black bodies not an African worldview.

That is, their social agency centered on their identification as members of the society who recursively reproduced its ideas and ideals as people with black skin not as Africans with a distinct worldview (language, communicative discourse, ideology, ideological apparatuses, and modes of production) from that of their former slave masters and colonizers by which they recursively reorganize and reproduce their being-in-the-world. As such, American blacks, as interpellated (workers) and embourgeoised agents of the American dominated global capitalist social structure of inequality, represent the most modern (i.e. embourgeoised) people of color, in terms of their "practical consciousness," in this process of homogenizing social actors as agents of the protestant ethic or disciplined workers working for owners of production in order to obtain economic gain, status, and upward mobility in the larger American society and the world.

Whereas, they once occupied the social space as agricultural and industrial workers, the former less educated than the latter, which were much wealthier because of their education and industrial work and therefore made education and industry the means to economic gain and upward economic mobility. Today, they continue to constitute the social space and their practical consciousness in terms of their relation to the means of production in post-industrial capitalist America. This relation differentiates black America for the most part into two status groups, a dwindling middle and upper class (living in suburbia) that numbers about 25 percent of their population (13 percent) and obtain their status as preachers, doctors, athletes, entertainers, lawyers, teachers, and other highend professional service occupations; and a growing segregated "black underclass" of criminals, unemployed, and under-employed wage-earners occupying poor inner-city communities and schools focused solely on technical skills, multicultural education, athletics, and test-taking for social promotion given the relocation of industrial and manufacturing jobs to poor periphery and semi-periphery countries and the introduction of low-end post-industrial service jobs and a growing informal economy in American urban-cities [57].

Whereas street and prison personalities, rappers, athletes, and entertainers, many of whom refer to themselves and their compa- 
triots as "my niggas," are the bearers of ideological and linguistic domination for the latter; the former, once called negroes, the black bourgeoisie (E. Franklin Frazier's term), and now African-Americans, is predominantly influenced by preachers and educated professionals as the bearers of ideological and linguistic domination. Both groups share the same ideals and goals, i.e., economic gain, status, and upward social mobility, within the class division and social relations of production of the Protestant capitalist world-system under American hegemony. Therefore, their practical consciousness is neither progressive, nor counter-hegemonic. It is reproductive and structurally differentiated.

However, America's transition to a post industrial, financialzed service, economy beginning in the 1970s, de-centred the negro (black bourgeoisie/African American) practical consciousness, and reified and positioned black American "my nigga" underclass ideology and language, hip-hop culture, as a viable means for black American youth to identify with and achieve economic gain, status, and upward economic mobility in the society over education and succeeding academically as emphasized by black bourgeois discourse. Finance capital in the US beginning in the 1970s began investing in entertainment and other service industries where the inner-city language, street, prison, entertainment, and athletic youth culture of black America became both a commodity and the means to economic gain, status, and upward mobility for the black poor in America's post industrial economy, which subsequently outsourced its industrial work to semi-periphery nations thereby blighting the inner-city communities.

Blacks, many of whom migrated to the northern cities from the agricultural south looking for industrial work in the north following the Civil War (1861-1865), became concentrated in blighted communities where work began to disappear, schools were underfunded, and poverty increased. The black migrants, which migrated North with their Black/African-American English Vernacular (BEV/AAEV) from the agricultural South, became segregated sociolinguistic underclass communities, ghettoes, of unemployed labourers looking to illegal, athletic, and entertainment activities (running numbers, pimping, prostitution, drug dealing, robbing, participating in sports, music, etc.) for economic success, status, and upward mobility. Educated in the poorly funded schools of the urban ghettoes, given the process of deindustrialization and the flight of capital to the suburbs, with no work prospects, many black Americans became part of a permanent, BEV/AAEV speaking and poorly educated underclass looking to other activities for economic gain, status, and upward economic mobility. Those who were educated became a part of the social class language game of the Standard-English-speaking black middle class of professionals, i.e., preachers, teachers, doctors, lawyers, etc. (the black bourgeoisie), living in the suburbs, while the uneducated or poorly educated constituted the social class language game of the black underclass of the urban ghettoes where the streets, prisons, athletics, and the entertainment industries became the ideological apparatuses for their socialization. Beginning in the late 1980s, finance capital be- gan com modifying and distributing (via the media industrial complex) the social class language game of the underclass black culture for entertainment in the emerging post industrial economy of the US over the ideology and language, social class language game, of the black bourgeoisie.

Be that as it may, efforts to succeed academically among black Americans, which constituted the ideology and language of the black bourgeoisie, paled in comparison to their efforts to succeed as speakers of Black English, athletes, "gangstas", "playas", and entertainers, which became the ideology and language of the black underclass living in the inner-cities of America. Authentic black American identity became synonymous with black underclass hip-hop ideology and language represented by young athletes and entertainers, Le Bron James, Derek Rose, Lil ' Wayne, Jay-Z, Kanye West, Tupac Shakur, Biggie Smalls, etc., over the social class language game of the educated black professional class under the ideological and linguistic domination of black preachers, TD Jakes, Creflo Dollar, Jamal Bryant, Juanita Bynum, etc., and other educated black professionals.

The black underclass in America's ghettoes has slowly become, since the 1980s, with the financialization of hip-hop culture as an art form and entertainment by record labels such as Sony and others, athletics, and the entertainment industry, the bearers of ideological and linguistic domination for the black youth community in America. Their language and worldview as constituted through the streets, prisons, hip-hop culture, athletics and the entertainment industry financed by finance capital, has become the means by which black youth (and youth throughout the world) attempt to recursively reorganize and reproduce their material resource framework against the purposive-rationality of educated black bourgeois or middle-class America. The upper-class of owners and high-level executives of the American dominated capitalist world-system have capitalized on this through the com modification of black "my nigga" underclass culture, which mainstreamed it.

This is further supported by an American media and popular culture that glorifies the streets, athletes, entertainers, and the "Bling bling," wealth, diamonds, cars, jewelry, and money. Hence the aim of many young blacks in the society is no longer to seek status, economic gain, and upward mobility through a Protestant Ethic that stresses hard work, diligence, differed gratification, and education; on the contrary, the Protestant ethic in sports, music, instant gratification, illegal activities (drug dealing), and skimming are the dominant means portrayed for their efforts through the entertainment industry financed by post-industrial capital. Schools throughout urban inner cities are no longer seen as means to a professional end in order to obtain economic gain, status, and upward mobility, but obstacles to that end because it delays gratification and is not correlative with the means associated with economic success and upward mobility in black urban America. More black American youth (especially the black male) want to become, football and basketball players, rappers and entertainers, like many of their role 
models, Le Bron James, Derek Rose, Lil ' Wayne, Jay-Z, Kanye West, Tupac Shakur, Biggie Smalls, etc., who were raised in their urban underclass environments and obtained economic gain and upward mobility that way, over doctors, lawyers, engineers, etc., the social functions associated with the status symbol of the black and white middle class (negroes) of the civil rights generation. Hence the end and social action of the larger society remains the same, economic success, status, and upward economic mobility, only the means to that end have shifted with the rise, financed by finance capital, of the black underclass as the bearers of ideological and linguistic domination in black America given the com modification of hip-hop culture and their high visibility in the media and charitable works through basketball and football camps and rap concerts, which reinforce the aforementioned activities as viable professions (means) to wealth and status in the society's post industrial economy, which focuses on services and entertainment for the world's transnational bourgeois class as the mode of producing surplus-value.

This linguistic and ideological domination and the ends of the power elites (rappers, athletes, gangsters) of the black underclass are juxtaposed against the Protestant Ethic and spirit of capitalism of the educated black middle and upper middles classes represented in the discourse and discursive practices of black American prosperity preachers in the likes of TD Jakes, Creflo Dollar, Jamal Bryant, Juanita Bynum, Eddie Long, etc. who push forth, via the black American church, education and professional jobs as the more viable means to economic gain, status, and upward economic mobility in the society over the street life of the urban ghettoes. Hence, whereas, for agents of the Protestant Ethic in the likes of Jakes, Dollar, Bryant, Bynum, and Long the means to "Bling bling," or the American Dream, is through education, obtaining a professional job, and material wealth as a sign of God's grace, salvation, and blessings. Rapping, hustling, sports, etc., for younger black Americans growing up in inner-cities throughout the US, where industrial work has disappeared, represent the means (not education) to the status position of "Bling bling."

\section{Discussion and Conclusion: Haitian Integration into the American Capitalist Social Structure}

Beginning in the late 1950s Haitians immigrated to the US differentiated within the racial-class socio-culture of Haiti previously highlighted. The first wave of Haitian immigrants to arrive in the US were predominantly your upper-class mulatto elites and members of the black grandon class escaping the Francois "papa-doc" Duvalier regime. They deemed the regime racist as it emphasized Duvalier's noirisme ideology, which highlighted Haiti as a black country that should be ruled by blacks against the mulatto elites who for so long dominated the nation's politics via what is referred to as politique de doublure (the politics of having a dark-skinned Haitian as the face of the government while the mulatto elites directed its politics and their racial-class interest) [2]. Highly educated, upon their arrival to the US, however, they became segregated from the larger mainstream society because of race, language, and culture, and the black American class structure because of language and embourgeoised French culture. Hence, Haitian practical consciousness early on evolved, segregated, by emphasizing the embourgeoised praxis of the mulatto elites and petit-bourgeois black grandson class of the island seeking to reproduce French culture and ideas among their children. In public, they established small businesses catering to the segregated Haitian population, emphasized upward economic mobility, the French language, the Catholic religion, playing a musical instrument, i.e., the piano, and professional education, i.e., law, medicine, and engineering, over the Kreyol language and Vodou religion of the African masses on the island.

Following the fall of the Duvalier regime in 1986, more Haitian immigrants from the provinces and mountains began emigrating from the island to the US escaping the political repression of anti-Jean Bertrand Aristide forces and the American embargo, which sought to get the latter to adopt neoliberal policies [8]. Proselytized by American Protestant missionary forces allowed on the island under the Duvalier regime to provide social welfare to the masses in place of government institutions, many of these recent immigrants to the US were anti-Vodou (given their Protestant indoctrination), poorer, less educated, Protestant, and Kreyol speaking. Upon their arrival to the US they became segregated in poorer Haitian communities in proximity to the black inner-city communities of the black American underclass as wealthier Haitians had, following the black American bourgeoisie, relocated to the suburbs.

In facing the discriminatory effects of the black underclass the practical consciousness of their children became divided between the embourgeoised aspirations of their parents seeking to follow the practical consciousness of the previous immigrant generation and the shifting American post industrial economy, which began to valorised the practical consciousness of the black underclass as en framed by the athletics industry and "Hip-Hop" culture as means to economic gain, status, and upward mobility in the larger society.

As such with the rise of the Haitian rapper Wyclef Jean to prominence in the early 90s, the "my nigga" practical consciousness of the black underclass took hold among young Haitian immigrants who integrated and reproduced elements of it amongst themselves in their own segregated poor communities. Against the embourgeoisement of their parents, they sought economic gain, status, and upward mobility via athletics, hustling, and the entertainment industry. Becoming Haitian flag waving, Jesus loving, Vodou hating, and Ebonics speaking Haitians whose only connections to Haiti were and are a broken form of Kreyol synthesized with English, Wyclef, Kodak black (another rapper), zo pound (a Haitian gang that developed in the inner-cities of Miami to protect Haitians who were discriminated against by African Americans), soup joumou (the independence day soup eaten by Haitians on January 1st), griot (fried pork prepared by Haitians), and the annual Haitian flag day festival in Miami held annually on May $18^{\text {th }}$.

Like many black Americans of the late 1980s and 90s who turned to roots and an Afro centric culture to combat both the pathologies 
of the black bourgeoisie and under classes, in response to both the "my nigga" Haitian identity and the French embourgeoisement of earlier generations, the middle-age children of the first generation of Haitian immigrants have begun to return to their Vodou and Kreyol roots in search of an authentic Haitian identity by which to recursively reorganize and reproduce their being-in-the-world. For now, in the age of globalization and post-industrialism, "the nigga" Haitian identity dominates in the US and is starting to take hold on the island over the latter two.

\section{References}

1. Jameson, Fredric, Masao Miyoshi (1998) The cultures of globalization Duke University Press, Durham, Carolina, USA.

2. Du Bois WEB (1995) The souls of black folk. Penguin Putnam Inc, New York, USA.
3. Genovese, Eugene (1974) Roll jordan roll. Pantheon Books, New York, USA.

4. Mocombe PC (2004) Who makes race matter in post-industrial capitalist America? Race Gender \& Class 11(4): 30-47.

5. Wilson Kirt H (1999) Towards a discursive theory of racial identity: the souls of black folk as a response to nineteenth-century biological determinism. Western Journal of Communication 63(2): 193-215.

6. Wilson, William J (1978) The declining significance of race: blacks and changing American institutions. The University of Chicago Press, Chicago, USA.

7. Wilson, William J (1987) The truly disadvantaged. University of Chicago Press, Chicago, USA.

8. Sennett, Richard (1998) The corrosion of character. Norton \& Company, New York, USA
Creative Commons Attribution 4.0

International License

For possible submissions Click Here
Submit Article

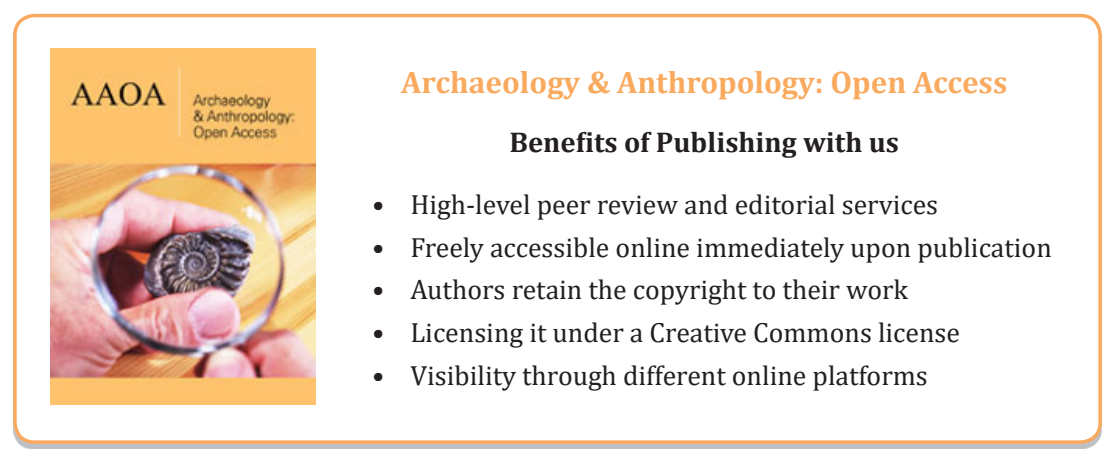

